\title{
The Role of Spiritually Transformative Experiences in Religious History and the Development of a Scale to Measure Them
}

\author{
Stanley Krippner, Ph.D. \\ Saybrook University
}

\begin{abstract}
Spiritual experiences are a potent means by which a person's attitudes and behaviors may be changed, usually (but not always) in benevolent ways. This article presents examples from various times and places, many from the annals of organized religion. Research into spiritually transformative experiences is reviewed as is a means to measure spiritual content in written or verbal reports: the Casto Spirituality Scoring System. This instrument includes subscales regarding spiritual settings, spiritual objects, spiritual characters, spiritual emotions, spiritual activities, and spiritual experiences. The reliability of the system has been examined and found to be quite high. In addition, the system has been useful clinically when spirituality becomes an issue in counseling or psychotherapy.
\end{abstract}

KEY WORDS: spirituality, transformation, dreams, Casto Spirituality Scoring System.

The word "transpersonal" was first introduced into human discourse by William James in a 1905 lecture (Vich, 1988). In 1942, Carl Jung used the German term uberpersonlich, which his English translators rendered as "transpersonal" in the phrase "transpersonal uncon-

\footnotetext{
Stanley Krippner, Ph.D., is the Alan Watts Professor of Psychology at Saybrook University. In 2000 he was the recipient of the American Psychological Association's Award for Distinguished Contributions to the International Development of Psychology. He is a Fellow of several organizations including the Society for the Scientific Study of Religion and the Association for Psychological Science and is the author or co-author of several books including The Voice of Rolling Thunder. This article is based on Dr. Krippner's presentation at the inaugural conference of the American Center for the Integration of Spiritually Transformative Experiences (ACISTE) in October of 2012. Preparation of this article was supported by the Saybrook University Chair for the Study of Consciousness. Correspondence regarding this article should be sent to Dr. Krippner at skrippner@saybrook.edu.
} 
scious" as a synonym for "collective unconscious" (Vich, 1988). A few years later, in 1949, Gardner Murphy used the term "transpersonal," and still later, in 1967, Abraham Maslow, Stanislav Grof, and Anthony Sutich used it (Sutich, 1976, pp. 15-16). The term is now applied to a variety of human behaviors and experiences. "Transpersonal studies" can be defined as disciplined inquiry into those observed or reported human behaviors and experiences in which one's sense of identity appears to extend beyond its ordinary limits to encompass wider, broader, or deeper aspects of humanity, life, and/or the cosmos including purported divine elements (Krippner, 1997). Transpersonal experiences are those that transcend the usual personal limits of space and/or time (Grof, 1967).

One current focus of transpersonal studies is a type of dream or other human experience in which people believe they have interacted with spiritual entities or domains and that this interaction has had long-lasting consequences. These experiences have been described in different ways: numinous-filled with numen, or divine power; transcendent-establishing contact with higher or "divine" existence; or sacred-encountering something considered to be hallowed, holy, and inviolate. In 1996, Yvonne Kason used the term "spiritually transformative experiences" to describe these experiences, and the term seems to be a useful one.

For example, Jung spoke of the "Self" archetype as the center of the psyche. This "Self" attempts to integrate all opposing elements of the psyche, transmuting them into a unique entity representing all that a person is able to become. In dreams, this process of integration, or "individuation," can appear as a flower, such as the Golden Flower of Taoism or the rose window of medieval Christian cathedrals; a geometric form, such as the circular mandala found in Tibetan Buddhism and many Native American medicine wheels; a jewel, such as the Blessed Pearl of Islam or the Jeweled Net of Indra; a person, such as Buddha, Jesus, Muhammad, or Lord Krishna; or a common object that takes on new meaning, such as the wheel of Hinduism, or the drum of the Lakota Sioux.

\section{Spiritually Transformative Dreams and Other Experiences throughout Religious History}

Dreams have played a major role in religious and spiritual traditions throughout the world (Cunningham, 1992; Klemp, 1999). The Carthaginian philosopher Tertullian wrote, "Nearly everyone knows that 
God reveals himself to people most often in dreams" (in Savary, Berne, \& Williams, 1984). Christians are familiar with the biblical account of St. Joseph's dream in which the agency of Mary's pregnancy was revealed. Another biblical dream warned the Eastern Magi to return to their country without revealing the whereabouts of Jesus to King Herod. Joseph was warned in a dream to take Mary and Jesus into safety because Herod was seeking to destroy the child; in addition, he learned from a dream when it was safe for him to return to Israel.

Queen Maya, the mother of the Buddha, reportedly had a dream in which a white elephant with six tusks entered her womb, indicating that she would give birth to an infant who would become a universal monarch. King Cudhodana, father of the Buddha, also dreamed about his son's path and was saddened by the separation it predicted. Gopa, Buddha's wife, dreamed of catastrophic events and shared it with her husband who explained that world turmoil heralds a potential inner liberation. In the 6th century, the mother of Prince Shotokutaishi dreamed that a Bodhisattva asked to take shelter in her womb. She soon became pregnant and gave birth to the individual who was to establish Buddhism in Japan.

The Talmud contains 217 references to dreams, and the Bible's Old Testament contains about 15 dreams, most of which herald the beginning of vital stages in Judaism's history. For example, Joseph attained eminence by interpreting the Egyptian Pharaoh's dreams. Earlier, his father, Jacob, is said to have undergone a transformative experience as the result of a dream. Jacob was hardly an appropriate figure to be the patriarch of Israel. At one point, he had refused to feed his hungry brother Esau until the latter surrendered to him the rights of the firstborn. In conspiracy with his mother, Jacob undertook an elaborate deception to take advantage of his father's blindness and to cheat Esau out of a paternal blessing. Later, when Jacob made a journey, he had a powerful dream in which he saw a ladder stretching from earth to heaven, with angels ascending and descending the steps. At the top of the ladder, God stood and proclaimed that He would give all the surrounding land to Jacob and his descendants. In such a manner, the apparently unrighteous brother was chosen over the pious one. Jacob, shaken by the dream, slowly mended his ways and, years later, offered Esau his wives, sons, servants, and animals. Esau refused the gifts out of love, and the two brothers were reconciled.

Most of the followers of Muhammad dispute reports that his revelations occurred in dreams (e.g., el-Aswad, 2012; McDonald, 1909). They point out that the Prophet's personal development was so highly 
evolved that there was no dividing line between his "conscious" and "unconscious." His "night journeys," whatever their origins, were spiritually transformative experiences. In about the early 17th century, Muhammad was resting in Mecca when the archangel Gabriel appeared with a winged steed that carried them to a mosque in Jerusalem where Muhammad led a number of prophets in prayer. From there, he toured the circles of heaven, speaking with Abraham, Moses, and Jesus, and finally was taken by Gabriel to Allah who began to dictate the Koran to him. These journeys lasted for a dozen years, during which time Muhammad would recite the words of Allah to scribes, because he was illiterate. This series of spiritually transformative experiences gave birth to the major religious movement of Islam.

One of Muhammad's followers, Abdullah ben Zayd, also reported a spiritually transformative dream that played an important role in the development of Islam. Muhammad was eager to introduce a recognizable call to prayer for the faithful, just as the Jews were called to the synagogue with a trumpet and the early Christians to church by the sound of a rattle. During prayers, ben Zayd fell asleep and dreamed of a man dressed in green who was carrying a rattle. Ben Zayd asked if he could buy the rattle to use as a call to prayer. The man in green replied, "Call out, There is no god but God and Muhammad is his Prophet." Upon awakening, ben Zayd told Muhammad of his dream, and the Prophet instructed him to teach the exact phrase he had heard to another follower, who became the first muezzin.

Francis of Assisi, the 13th century monk who founded the Franciscan order, was about to have an interview with the terrifying Pope Innocent III. It is reported that he dreamed he had grown as tall as a great tree and, as Innocent looked on in dismay, restored the balance of a Vatican basilica that was on the point of collapsing. This dream gave St. Francis the courage to tell the pope that his order was badly needed to restore vigor to the Roman Catholic Church. St. Dominic, who founded a rival religious order, reported a dream of being presented to Jesus and the Virgin Mary in the company of St. Francis. The two of them were jointly entrusted with the conversion of the world.

Spiritually transformative dreams can also illuminate intrapersonal religious conflicts. St. Francis had a dream series in which his fiancée, present in the first dream, was replaced by the Virgin Mary, signifying his rejection of secular life. A 12th century Jain text tells the story of Kesara and Vasanta. One night, Kesara dreamed that she married Vasanta, and that same night he dreamed that he married 
her. Both were delighted with the dream message and declared their mutual love. But Kesara's parents, as was the custom, had arranged her marriage to someone else, based on such traditional practices as favorable astrological signs. They considered their daughter's dream an illusion and disregarded their daughter's pleas. Saddened, Kesara and Vasanta tried to commit suicide. Fortunately, they were rescued, escaped their parents, and lived together happily.

The establishment of the Church of the Latter Day Saints was associated with dream revelations that Joseph Smith purportedly received in 1820. He dreamed that God told him to establish a church and, in 1823, the angel Moroni appeared in a dream and revealed to him the existence of the Book of Mormon. Bulkeley (1995) observed that religion was the original field of dream study, and that dreams are major spiritual phenomena in almost all of the world's religious traditions.

In some eras, religious institutions have taken a hostile attitude toward dreamworkers and dreamworking. In some meditative disciplines, it is maintained that spiritually developed adepts do not need to dream. In the 5th century, St. Jerome's translation of the Bible from Greek and Hebrew manuscripts was marred by his substitution of "observing dreams" for "witchcraft" in several parts. Therefore, the new translation dogmatically stated, "You will not practice soothsaying or observe dreams." As a result, the Roman Catholic Church held dreamwork in disfavor for the next 15 centuries; people were discouraged from turning to their dreams for insight, consolation, or hope. It is not known whether St. Jerome or the church authorities were responsible for the error in translation, but it appears to have been deliberate because the word "witchcraft" is correctly used in other portions of the translation (Savary, Berne, \& Williams, 1984).

In the history of religion, dreams have not been the only vehicle for spiritual transformation. On his first three trips outside the palace, the Buddha saw sickness, old age, and death, asking himself, "How can I enjoy a life of pleasure when there is so much suffering in the world?" On his fourth trip, he met a wandering monk who had given up everything, and the Buddha resolved to follow the same path. For six years, he practiced extreme asceticism, but no spiritually transformative experience was forthcoming. He then started to eat nourishing food, began to regain his strength, and resolved to sit under a Bodhi tree until he found an answer to his question. Following temptations and conflicts, he had a spiritually transformative experience, understanding the cause of suffering and how to resolve it. For the next 45 years, he taught the three universal truths, the eightfold path, and the 
five precepts. Many of those who follow these teachings have reported spiritually transformative experiences themselves.

In addition to dreams, other types of spiritually transformative experiences played a crucial role in Christian history. St. Paul's vision of Jesus on the road to Damascus stopped his zealous persecution of Christians, and he became a Christian activist, spreading the new doctrine around the Mediterranean world. In $314 \mathrm{CE}$, the Emperor Constantine, in the midst of a battle, reported a vision of a cross superimposed on a sun bearing the message "In this sign, conquer." He went on to win the battle and demanded that his entire kingdom convert to Christianity, thus spreading the doctrine to the Middle East.

The girl who was to be known as Joan of Arc began hearing voices in 1425 at the age of 13 years. English and Burgundian forces had burned the French town of Domremy located near the home of Joan and her family. Joan's voices were accompanied by white light and by St. Michael, St. Catherine, and St. Margaret. The latter two saints died as martyrs, as did Joan in 1431, but not until she had motivated the French ruler to assert his power and end the English occupation of France.

At the age of 19, Andrew Jackson Davis had only spent five months in a school and had read but a handful of books. Nonetheless, he had a spiritually transformative experience in which he entered what he called a "higher sphere" that triggered a career that involved intuitive diagnoses and prescriptive measures for serious diseases. He also wrote a series of books that covered such topics as astronomy, biology, education, government, medicine, philosophy, and physics. He was best known for The Principles of Nature, a 700-page treatise published in 1847 that achieved great popularity. During the War Between the States, he held séances in Washington, DC, where he communicated with spirits and made predictions. Mary Todd Lincoln attended some of these séances, and it is possible that her husband did as well. This example demonstrates that STEs need not occur within the framework of an organized religion.

Susan Champion de Crispgny was a member of a distinguished military family and married into English nobility. She was a devout Christian as well as an acclaimed novelist, poet, and advocate of women's suffrage. She attended a Theosophical meeting that evoked a spiritually transformative experience that quickly led her to leadership roles in several spiritualist organizations in Great Britain in the 1920s and 1930s.

Spiritually transformative experiences sometimes lead to benevo- 
lent outcomes, but sometimes do not. When Sister Teresa of Albania was traveling to Darjeeling, India, in 1946, she heard God tell her that her life's work was to recognize the divinity of the poorest of the poor and to serve them with love. She founded an order, became known as Mother Teresa, and was awarded the Nobel Peace Prize. Fifty years later, in 1996, an Israeli student heard God give him orders to kill the Israeli Prime Minister Yitzchak Rabin, another Nobel Laureate. He followed these orders, and Rabin's death had disastrous consequences for peace in the Middle East.

\section{Research Studies in Spiritual Dreams}

Although dreams have been perceived to play a role in the spirituality of individuals and groups since ancient times, modern dream researchers have paid little attention either to their content or to their significance in contemporary life. Interviews and conversations with individuals who report spiritual dreams, however, indicate that they often are perceived to have significance and value to the dreamers (Bulkeley, 1995; Savary, 1990). These attitudes involve how the dreamers perceive the world and how they conduct themselves in it, typically in terms of manifesting greater serenity, more facile decision-making capabilities, an appreciation for aspects of life described as "divine," and an increased satisfaction with their social and professional activities. In addition to enhanced outcomes in dreamers' waking lives, there are also indications that spiritual dreams may sometimes have negative consequences, such as misguiding the dreamer into actions that result in personal distress (Robbins, 1988, pp. 143-145).

Some research studies have demonstrated a relationship between spiritually transformative experiences and positive outcomes in individuals' lives, such as psychological wellbeing and improved psychological attitudes (e.g., Hood, 1974; Kaas, Friedman, Lesserman, Zuttermeister, \& Benson, 1991; Noble, 1987; Pollner, 1989) as well as enhanced relationship to the world, for example, investigating the purpose of life and their place in that purpose (e.g., Grof, 1988, p. 265; James, 1902/1958, p. 389). Because waking spiritually transformative experiences have been found to play a role in enhanced life outcome, a similar relationship with spiritual dreams, if it exists, may indicate that these dreams may also become a catalyst for enhanced quality of life.

In the literature of spirituality and dreaming, the content and use of spiritual dreams in the lives of individuals typically have been ex- 
amined, through descriptions of personal experiences, historical anecdotes, and ethnographic dream accounts. Some of these dream accounts include specific content perceived by the dreamer to be spiritual, such as light (Boteach, 1991, p. 146; Gillespie, 1989, p. 489; Sanford, 1989, p. 43), divine entities (Savary, Berne, \& Williams, 1984, pp. 16-17), and spiritual teachers (Evans-Wentz, 1958; Shaw, 1992, pp. 56-71). Other dream accounts include experiences perceived by the dreamer to be spiritual, such as the oncoming of death (Sanford, 1989, p. 43; Wren-Lewis, 1985/1991, pp. 77-78), experiences of transcendence and awe (Busnik \& Kuiken, 1996), and the entry into spiritual domains (Kelsey, 1974, p. 111; Strickmann, 1988, p. 39; Tedlock, 1987). Esoteric practices in dreams (Eliade, 1987, p. 489; Kilborne, 1990, pp. 198-199) and Tibetan dream yoga practices (Sogyal Rinpoche, 1992, p. 108) also have been considered to be spiritual.

There is some published research into what Jungians call "archetypal" dreams, for instance, dreams that reflect supposedly "universal" themes or vivid images from mythology, folklore, and/or religion (Faber, Saayman, \& Touyz, 1978, p. 2; Spadafora \& Hunt, 1990). In addition, there is a body of research involving lucid dreams and/or meditation and dreams (Gackenbach, Cranson, \& Alexander, 1986, pp. 34-40; Hunt \& Ogilvie, 1988, p. 12, Kelzer, 1987). However, archetypal dreams and lucid dreams are not spiritual dreams per se, and most of the studies involving them did not distinguish spiritual dreams from other types of dreams. An exception is the work of Busnik and Kuiken (1996) who asked 36 men and women to report their most "impactful" dreams from the preceding month. Cluster analysis identified five groupings, one of which, "transcendence," was marked by feelings of "joy, delight, ecstasy, and awe." The overall results constituted a partial replication of an earlier study (Kuiken \& Sikora, 1993).

One of my students at Saybrook University, Kira Lynn Casto and I embarked on a different kind of research procedure that would identify "spiritual dreams." We selected content analysis to accomplish this objective because this method has been developed to systematically and objectively identify characteristics and themes of communications or documents and the relative extent to which these characteristics and themes pervade a given communication or document (Berg, 1989, p. 106; Holsti, 1968, pp. 597, 601; Weber, 1990, p. 9). Since 1888, many researchers have used content analysis to investigate dream content (Winget \& Kramer, 1979), but few have focused specifically on the spiritual content of dreams. We asked the research 
question, "Can the spiritual content of dream reports be identified and measured?"

"Dreaming" is defined by the American Heritage Dictionary (1993) as a sequence of images, ideas, and/or emotions that occur during sleep. Dreams are generally reported in narrative form. Hall and Nordby (1972) have noted that dream researchers need to attempt to distinguish between the dreamer's subjective experience, the dreamer's memory of the dream and reflections on the dream experience, and the dreamer's verbal, artistic, or other ways of reporting the experience.

Images, or imagery, in dreams are defined in the same way that Achterberg and Lawlis (1980) defined "imagery," as, "the internal experience of a perceptual event in the absence of the actual external stimuli" (p. 27). Therefore, imagery in dreams does not have to be visual but can be auditory, olfactory, gustatory, or kinesthetic. In this investigation, the definition of "dreaming" was any reported imagery or other mental/emotional content that the dreamer claimed to have experienced during sleep. Self-awareness without content during sleep, as well as content reported from guided imagery, waking fantasies, meditative states, or other altered states of consciousness not occurring during sleep were excluded from this research.

"Spiritual" was defined as one's focus on, and/or reverence, openness, and connectedness to something of significance believed to be beyond one's full understanding and/or individual existence (American Heritage Dictionary, 1993; Elkins, Hedstrom, Hughes, Leaf, \& Saunders, 1988; Krippner \& Welch, 1992, pp. 5, 122; Shafranske \& Gorsuch, 1984, p. 233). This definition was crucial to our research because, as Ken Wilber (1999) noted, the answer to questions about spirituality depends upon how one defines the term (p. 4).

In this research, the "divine" was defined as that which is regarded as holy-belonging to, derived from, or associated with religious or spiritual powers; and/or sacred - that which is dedicated to or worthy of veneration or worship (American Heritage Dictionary, 1993), thus deserving the highest respect. The locus of the divine can be either outside of oneself, as when it has the nature of a superhuman entity or a deity, or within oneself, as when it is thought to reside within one's "inner," "deeper," and/or "higher" self. "Reverence," in this research, was defined as an attitude or feeling of profound awe and respect (American Heritage Dictionary, 1993).

Definitions of "spiritual" and "religious" and of "spirituality" and "religion" are often similar. For example, James (1902/1958) defined "religion" as "feelings, acts, and experiences of individual men [and 
women] in their solitude, so far as they apprehend themselves to stand in relation to whatever they may consider divine" (p. 42). However, this definition is very much like the definition of "spiritual" as given above, especially in its implied link between beliefs and action (Reese, 1997). Therefore, for clarity's sake, "religion" or "religious" was distinguished in this research from "spiritual" as pertaining to, and adherence to, an organized system of beliefs about the divine, and the observance of rituals, rites, and requirements of that organized system of beliefs (American Heritage Dictionary, 1993). Spiritual, on the other hand, referred to activity and experience, especially one's direct contact with the dimensions of existence one considers "sacred" (Walsh, 1999, p. 3).

\section{The Casto (1995) Spirituality Scoring System}

Many previous researchers have used Calvin Hall and Robert Van de Castle's (1966) system of dream content analysis, with its predetermined categories and subcategories, to detect common and recurring elements in dreams. Although Hall and Van de Castle's (1966) categories do not include spiritual categories per se, they do include categories that sometimes contain spiritual content items, for example, physical surroundings, characters, social interactions, activities, achievement outcomes, environmental press, emotions, and descriptive elements. Hall and Van de Castle (1966) found the reliability of scoring, or consistency of measurement, to be $73 \%$ for physical surroundings, $76 \%$ for characters, $70 \%$ for social interactions, $85 \%$ for activities, and $63 \%$ for emotions. Hall and Van de Castle's (1966) original normative data has been replicated in other studies; for example, G. William Domhoff and his associated (Hall, Domhoff, Blick, \& Weesner, 1982) found few differences between the normative data of Hall and Van de Castle's original research and their own participants.

With this information in mind, Casto developed a "spirituality" system to supplement Hall and Van de Castle's system (Casto, 1995). Named the "Casto Spirituality Scoring System" (CSSS), she modified several categories in Hall and Van de Castle's (1966) system to identify spiritual content (Figure 1). Their "Objects" category was altered to "Spiritual Objects," their "Characters" category was altered to "Spiritual Characters," their "Settings" category was altered to "Spiritual Settings," their "Activities" category was altered to "Spiritual Activities," and their "Emotions" category was altered to "Spiritual Emotions." 
SPIRITUAL OBJECTS: Objects used for focus, and reverence, to open and connect one to something of significance that is believed to be beyond one's full understanding and/or individual existence.

SPIRITUAL CHARACTERs: People, animals, or beings that are meaningfully connected to something of significance that is believed to be beyond one's full understanding and/or individual existence and that one associated with a sense of reverence.

SPIRITUAL SETTINGs: Places where one feels meaningfully connected to something of significance believed to be beyond one's full understanding and/or individual existence and that are associated with a sense of reverence.

SPIRITUAL ACTIVities: Activities used to open and connect one to something of significance believed to be beyond one's full understanding and/or individual existence and that are associated with a sense of reverence.

SPIRITUAL EMOTIONS: Felt emotions that are regarded as meaningfully related to something of significance that is believed to be beyond one's full understanding and/or individual existence, associated with a sense of reverence.

SPIRITUAL EXPERIENCES: Experiences in which a sense of direct contact, communion, or union with something that is considered to be ultimate reality, God, or the divine; and/or experiences in which one's sense of identity temporarily reaches beyond or extends past one's ordinary personal identity to include an expanded perspective of humanity and/or the universe; and/ or experiences in which one appears to enter a sacred realm or condition that goes beyond the ordinary boundaries of space and linear time.

Figure 1. Casto Spirituality Scoring System. 
Casto (1995) used Ralph Hood's (1975) Mysticism Scale to develop a "Spiritual Experiences" category yielding several possibilities, i.e., experiences in which there is a sense of direct contact, communion, or union with something considered to be ultimate reality, God, or the divine; experiences in which one's sense of identity temporarily reaches beyond or extends past one's ordinary personal identity to include an expanded perspective of humanity and/or the universe; and experiences in which one appears to enter a sacred realm or condition that goes beyond the ordinary boundaries of space and linear time.

The difference between "Activities" and "Experiences" is similar to the psychological differentiation between behavior, that is, externally observable actions including verbal behavior, and experience, that is, lived events that are phenomenological reported. The phrase, "I was angry at God" would be scored for "spiritual emotion." The phrase, "I told God that I was angry" would be scored for both "Spiritual Emotion" and "Spiritual Activity." The phrase, "I was angry at God, and this reaction produced a red glow in my heart that sent intense heat throughout my body" would be scored for "Spiritual Emotion" and "Spiritual Experience." The phrase, "I told God that I was angry, and this reaction produced a red glow in my heart that sent intense heat throughout my body" would be scored for "Spiritual Emotion," "Spiritual Activity," and "Spiritual Experience."

These content definitions could apply to dreams reported from individuals representing a wide variety of spiritual backgrounds. One dreamer might report dreaming about "an intense ecstatic experience accompanied by white light conveying a blessing by Jesus Christ," another might report an intense ecstatic dream experience accompanied by white light that is felt to be a precursor to "the Nirvana described by the Buddha," and still another might report an intense ecstatic dream experience accompanied by white light that represents the arrival of Oxala, the African-Brazilian orisha (i.e., deity) of purity. All three dreams would be scored for "Spiritual Experience," for "Spiritual Activity" (e.g., the blessing, the description, the arrival), for "Spiritual Object" (e.g., the white light), and "Spiritual Character" (e.g., Jesus Christ, the Buddha, Oxala), despite the disparate traditions represented.

To evaluate reliability, the scores of two judges using the CSSS were compared (Casto, Krippner, \& Tartz, 1999). A content item was not judged to be "Spiritual" unless it had received scores from both judges. Each dream was compared for presence or absence of each content category. Correlations reported by the two judges using the CSSS 
were .946 for "Spiritual Objects," .943 for "Spiritual Characters," .918 for "Spiritual Settings," .946 for "Spiritual Activities," .993 for "Spiritual Emotions," and .929 for "Spiritual Experiences." The reliability of the CSSS as a whole was .946, which indicates high reliability between scorers. An agreement between raters was counted if either both raters scored a spiritual dream element for a particular dream or both raters did not score a spiritual dream element for a particular dream. An example of a dream report neither judge scored as having spiritual content was:

I am playing with my friend, but something is chasing us. It was like my father or a huge shadow. My friend could run with a great deal of speed, but I could not move quickly enough. I was about to be captured, but my friend was safe because he was able to run faster. (p. 50)

\section{Examples using the CSSS Casto Spirituality Scoring System.} Casto (Krippner, Jaeger, \& Faith, 2001) once worked with a female client who reported a spiritually transformative experience following a dream:

In my dream, I was lying on my side, facing a wall. I propped myself up on my elbow as I stared at a white flickering illumination of a Madonna that was facing the same wall, praying. I stared at it, gathering my wits for a few moments. I was not afraid. I was awestruck. It occurred to me that this was some kind of message from my Mom who only months ago died. I wanted it to be a message from her, so I waited for the Madonna to speak to me. But it only faced the wall, oblivious to me. It wore a white flowing robe with a drape over its head. And then the face changed into my face. It was my face as a teenager. I watched in amazement as the figure clenched its fists to its breasts and threw its head back to scream this silent anguished scream. I thought, "My goodness, that's me. That's how I feel." I was startled by this but I immediately felt like the world or God or my Mom had recognized my pain. I then actually woke up in bed. (pp. 143-144)

Casto and her client worked with the dream, finding indications that the dreamer's life options were limited or blocked in some way. Such phrases as "it only faced the wall," "the figure clenched its fists to its breasts," and "this silent anguished scream" suggested that something was holding her back. Perhaps the dreamer's grief was blocking her action, but, at the same time, providing a comforting link with her mother. The anguish that the dreamer recognized in herself appeared to be a breakthrough in the grieving process that accompanied her mother's death, especially because it seemed to bring to her 
an acknowledgement that her pain was recognized by presences beyond herself. The discussion of this dream helped Casto's client work through the grief surrounding her mother's death, and released the energy required to explore options and make plans for the future.

An adult client whom I'll call Adele brought a dream to me that had originally recurred for about three years when she was a child and had recently returned. The setting of the dream was a hilly countryside, and the dreamer was seated outside a cave that seemed to be sacred. As she waited expectantly, a faceless monk in a black robe entered the sacred cave, chanting, "In time I come for everyone." Adele's feelings were fear, respect, and reverence. This dream report became a spiritually transformative experience, enabling Adele to examine the existential issues surrounding death, as it occurred at a time in her life when she had become acutely aware that she might lose her family members to death. Eventually, Adele resolved these fears by focusing on the feelings of respect and reverence in her dreams, concluding that death is part of the life process and that an awareness of its inevitability enhances the immediacy and enjoyment of each daily activity.

A clinical psychologist used the Casto scale when working with a client who reported a dream that triggered a spiritually transformative experience (Casto, Krippner, \& Tartz, 1999). The client was in his late 20s when he dreamed that he was a young man, and everything was bright and new. Suddenly, he changed into an old man, and life's freshness seemed to have faded. Now the only certainty that the future held was death. The dreamer thought that if he meditated, he would become eternal. He had begun to meditate when the myth of Gilgamesh came to mind. He then realized that his attempt was futile, because, like Gilgamesh, he would have to die. But, like Gilgamesh, he resolved to make himself useful to society and live in the present moment.

This dream was transformative in affecting therapeutic change in this client. One of the dream's main themes is the realization of death's imminence accompanied by fear. Another theme is the dreamer's attempt to escape his demise through spiritual practices, but his realization that this goal is futile. Finally, the dream encouraged the dreamer to take an active role in his life in contrast to his usual passivity. The client followed up this insight in therapy by molding his interpersonal relationships in a more positive manner and by becoming an active member of society, participating in organizations committed to positive social change. 
These three dreams illustrate the way that symbols, metaphors, and mythic elements convey meaning in spiritually transformative dreams. They were scored for "Spiritual Characters" (e.g., the Madonna, the "faceless monk," Gilgamesh), "Spiritual Settings" (e.g., the "sacred cave"), "Spiritual Activities" (e.g., praying, meditating), "Spiritual Emotions" (e.g., "I was awestruck," "feelings of respect and reverence"), and "Spiritual Experiences" (e.g., "I immediately felt like the world or God or my Mom had recognized my pain"). Each dream played an important role in shifting the dreamer's attitudes and behaviors in more positive directions characterized by greater intrapsychic, interpersonal, and spiritual wellbeing.

In this study (Casto, Krippner, \& Tartz, 1999) we asked if the spiritual content of spiritually transformative dream reports could be identified and measured. On the basis of the high reliability scores obtained by the judges, a tentative affirmative answer to this question seems warranted. In so far as the validity of the CSSS is concerned, Casto (1995), in her original study, found that her dreamers with identifiable spiritual content in their dream reports claimed to have had concomitant experiences in their daily lives.

\section{Conclusion}

In summary, people throughout history have reported spirituallyoriented dreams and other transpersonal experiences that have resulted in their own spiritual transformations and sometimes transformation of their worlds.

Previous work with content analysis (e.g. Munroe, Nerlove, \& Daniels, 1969) supported the contention championed by Alfred Adler (1938), Calvin Hall (Hall \& Nordby, 1972), and others that dream life mirrors waking life. If this is the case, the CSSS could be used to study the spiritual development of historical and contemporary personages who have reported spiritually transformative experiences, the spiritual states of clients undergoing transpersonally-oriented psychotherapy or counseling, the incidence of spiritual dream content in certain demographic groups, and cross-cultural studies of spiritual activity and interest (e.g., Heinze, 1991; Krippner \& Thompson, 1996). As a result, the scattered anecdotes about dream reports that seem to have been triggers to spiritually transformative experiences can yield insights into the nature of spiritual transformation even if they occurred in different times and places, different eras and different locations.

Our study (Casto, Krippner, \& Tartz, 1999) provided data that an- 
swered our research question positively and showed that the spiritual content of spiritually transformative dreams can be identified and measured using a system, the CSSS, based on a specific definition of "spiritual." The CSSS has already been used to identify spiritual elements in ayahuasca sessions (Krippner \& Sulla, 2000); ayahuasca is a mind-altering brew made from tropical plants that appears to evoke spiritual imagery and emotions; many of these experiences appear to be transformative. We believe it has the potential to assess the spiritual content of yet other experiences of altered consciousness and potential spiritual transformation, such as near-death experiences (Corazza, 2008) and "spiritual emergences" (Grof, 1998), neither of which typically involve nighttime dreams. The role played by spiritually transformative experiences in religious history as well as in the lives of ordinary people both historical and contemporary is an exciting area for those researchers interested in the field of transpersonal studies.

\section{References}

Achterberg, J., \& Lawlis, G. F. (1980). Bridges of the bodymind: Behavioral approaches to health care. Champaign, IL: Institute for Personality and Ability Testing.

Adler, A. (1938). Social interest: Challenge to mankind. London, England: Farber and Farber.

American Heritage Dictionary. (1993). [Computer program]. Redmond, WA: Microsoft. (Microsoft Bookshelf)

Berg, B. L. (1989). Qualitative research methods for the social sciences. Boston, MA: Allyn and Bacon.

Boteach, Y. S. (1991). Dreams. Brooklyn, NY: Bash.

Bulkeley, K. (1995). The wilderness of dreams. Albany, NY: State University of New York Press.

Busnik, R., \& Kuiken, D. (1996). Identifying types of impactful dreams: A replication. Dreaming, 6, 97-119.

Casto, K. L. (1995). Contemporary spiritual dreams: Their content and significance. Unpublished doctoral dissertation, Saybrook Institute, San Francisco, CA.

Casto, K. L., Krippner, S., \& Tartz, R. (1999). The identification of spiritual content in dream reports. Anthropology of Consciousness, 10, 43-53.

Corazza, O. (2008). Near-death experiences: Exploring the mind-body connection. London, England: Routledge.

Cunningham, S. (1992). Sacred sleep: Dreams and the divine. Freedom, CA: Crossing Press.

el-Aswad, e.-S. (2012). Muslim worldviews in everyday lives. Lanham, MD: Altamira Press.

Elkins, D. N., Hedstrom, L. J., Hughes, L. L., Leaf, J. A., \& Saunders, C. (1988). 
Toward a humanistic-phenomenological spirituality: Definition, description, and measurement. Journal of Humanistic Psychology, 28(4), 5-18.

Eliade, M. (1987). Dreams. In M. Eliade (Ed.), Encyclopedia of religion (pp. 482492). New York, NY: Macmillan.

Evans-Wentz, W. Y. (1958). The doctrine of the dream-state. In W. Y. EvansWentz (Ed.), Tibetan Yoga and secret doctrines (pp. 215-223). Oxford, England: Oxford University Press.

Faber, P. A., Saayman, G. S., \& Touyz, S. W. (1978). Meditation and archetypal content of nocturnal dreams. Journal of Analytical Psychology, 23, 1-22.

Gackenbach, J., Cranson, R., \& Alexander, C. (1986). Lucid dreaming, witnessing dreaming, and the Transcendental Meditation technique: A developmental relationship. Lucidity Letter, 5(2), 34-40.

Gillespie, G. (1989). Lights and lattices and where they are seen. Perceptual and Motor Skills, 68, 487-504.

Grof, S. (1967). Realms of the human unconscious: Observations from LSD research. New York, NY: E. P. Dutton.

Grof, S. (1988). The adventure of self-discovery: Dimensions of consciousness and new perspectives in psychotherapy and inner exploration. Albany, NY: State University of New York Press.

Grof, S. (1998). The cosmic game. Albany, NY: State University of New York Press.

Hall, C. S., Domhoff, G. W., Blick, K. A., \& Weesner, K. E. (1982). The dreams of college men and women in 1950 and 1980; A comparison of dream content and sex differences. Sleep, 5, 188-194.

Hall, C. S., \& Nordby, V. J. (1972). The individual and his dreams. New York, NY: New American Library.

Hall, C. S., \& Van de Castle, R. L. (1966). The content analysis of dreams. New York, NY: Appleton Century Crofts.

Heinze, R. I. (1991). Shamans of the 20th century. New York, NY: Irvington.

Holsti, O. R. (1968). Content analysis. In G. Lindzey \& E. Aronson (Eds.), The handbook of social psychology: Vol. 2. Research methods (pp. 597-601). Reading, MA: Addison-Wesley.

Hood, R., Jr. (1974). Psychological strength and the report of intense religious experience. Journal for the Scientific Study of Religion, 13, 65-71.

Hood, R., Jr. (1975). The construction and preliminary validation of a measure of reported mystical experience. Journal for the Scientific Study of Religion, 14, 29-41.

Hunt, H. T., \& Ogilvie, R. D. (1988). Lucid dreams in their natural series: Phenomenological and psychophysiological findings in relation to meditative states. In J. Gackenbach \& S. LaBerge (Eds.), Conscious mind, sleeping brain: Perspectives on lucid dreaming (pp. 389-417). New York, NY: Plenum.

James, W. (1958). The varieties of religious experience. New York, NY: Mentor. (Original work published 1902)

Kaas, J. D., Friedman, R., Lesserman, J., Zuttermeister, P. C., \& Benson, H. (1991). Health outcomes and a new index of spiritual experience. Journal for the Scientific Study of Religion, 30, 203-211.

Kason, Y. (1996). A farther shore: How near-death and other extraordinary experiences can change ordinary lives. San Francisco, CA: Harper Collins. 
Kelsey, M. T. (1974). God, dreams, and revelation: A Christian interpretation of dreams (rev. ed.). Minneapolis, MN: Augsburg.

Kelzer, K. (1987). The sun and the shadow: My experiment with lucid dreaming. Virginia Beach, VA: A.R.E. Press.

Kilborne, B. (1990). Ancient and native peoples' dreams. In S. Krippner (Ed.), Dreamtime and dreamwork (pp. 194-203). Los Angeles, CA: Tarcher.

Klemp, H. (1999). The art of spiritual dreaming. Minneapolis, MN: Eckenkar.

Krippner, S. (1997). Foreword. In D. Rothberg \& S. Kelly (Eds.), Ken Wilber in dialogue: Conversations with leading transpersonal thinkers (pp. ix-xi). Wheaton, IL: Quest Books.

Krippner, S., Jaeger, C., \& Faith, L. (2001). Identifying and utilizing spiritual content in dreams. Dreaming, 11, 127-147.

Krippner, S., \& Sulla, J. (2000). Identifying spiritual content in reports from ayahuasca sessions. International Journal of Transpersonal Studies, 19, 59-76.

Krippner, S., \& Thompson, A. (1996). A 10-facet model of dreaming applied to dream practices of sixteen Native American cultural groups. Dreaming, 6, 71-96.

Krippner, S., \& Welch, P. (1992). Spiritual dimensions of healing: From tribal shamanism to contemporary health care. New York, NY: Irvington.

Kuiken, D., \& Sikora, S. (1993). The impact of dreams on waking thoughts and feelings. In A. Moffit, M. Kramer, \& R. Hoffman (Eds.), The functions of dreaming (pp. 419-476). Albany, NY: State University of New York Press.

McDonald, D.B. (1909). The religious life and attitude in Islam. Chicago, IL: University of Chicago Press.

Munroe, R. L., Nerlove, S., \& Daniels, R. (1969). Effects of population density on food concerns in three East African societies. Journal of Social Psychology, $125,405-406$.

Murphy, G. (1949). Psychical research and personality. Proceedings, Society for Psychical Research, 49, 1-15.

Noble, K. D. (1987). Psychological health and the experience of transcendence. Counseling Psychologist, 15, 601-614.

Pollner, M. (1989). Divine relations, social relations, and well-being. Journal of Health and Social Behavior, 30, 92-104.

Reese, H. W. (1997). Spirituality, belief, and action. Journal of Mind and Behavior, 18, 24-51.

Robbins, P. R. (1988). The psychology of dreams. Jefferson, NC: McFarland.

Sanford, J. A. (1989). Dreams: God's forgotten language (2nd ed.). San Francisco, CA: HarperCollins.

Savary, L. M. (1990). Dreams for personal and spiritual growth. In S. Krippner (Ed.), Dreamtime and dreamwork (pp. 89-92). Los Angeles, CA: Tarcher.

Savary, L. M., Berne, P. H., \& Williams, S. K. (1984). Dreams and spiritual growth: A Christian approach to dreamwork. New York, NY: Paulist Press.

Shafranske, E. P., \& Gorsuch, R. L. (1984). Factors associated with the perception of spirituality in psychotherapy. Journal of Transpersonal Psychology, 16, 231-241.

Shaw, R. (1992). Dreaming as accomplishment: Power, the individual and Temne divination. In M. C. Jedrej \& R. Shaw (Eds.), Dreaming, religion and society in Africa (pp. 36-54). Leiden, Netherlands: E. J. Brill. 
Sogyal Rinpoche. (1992). The Tibetan book of living and dying. San Francisco, CA: HarperCollins.

Spadafora, A., \& Hunt, H. (1990). The multiplicity of dreams: Cognitive-affective correlates of lucid, archetypal, and nightmare dreaming. Perceptual and Motor Skills, 71, 627-644.

Strickmann, M. (1988). Dreamwork of psycho-sinologists: Doctors, Taoists, monks. In C. T. Brown (Ed.), Psycho-sinology: The universe of dreams in Chinese culture (pp. 25-46). Washington, DC: Woodrow Wilson International Center for Scholars.

Sutich, A. J. (1976). The emergence of the transpersonal orientation: A personal account. Journal of Transpersonal Psychology, 8, 5-19.

Tedlock, B. (1987). Dreaming and dream research. In B. Tedlock (Ed.), Dreaming: Anthropological and psychological interpretations (pp. 1-30). New York, NY: Cambridge University Press.

Vich, M. (1988). Some historical sources for the term "transpersonal." Journal of Transpersonal Psychology, 20, 107-110.

Walsh, R. (1999). Essential spirituality. New York, NY: John Wiley \& Sons.

Weber, R. P. (1990). Basic content analysis (2nd ed.). Newbury Park, CA: Sage.

Wilber, K. (1999). Spirituality and developmental lines: Are there stages? Journal of Transpersonal Psychology, 31, 1-10.

Winget, C., \& Kramer, M. (1979). Dimensions of dreams. Gainesville, FL: University of Florida.

Wren-Lewis, J. (1991). Dream lucidity and near-death experience: A personal report. Lucidity, 10th Anniversary Issue, 10, 75-79. (Original work published 1985) 